\title{
Education for Health in Communities with Weak Basic Sanitation in Sumbe
}

\author{
Maria Lusinga Secundua, Augusto José Fazenda* \\ Natural Sciences Department, Katyavala Bwila University, Sumbe, Angola \\ Email address: \\ mlsecundua@yahoo.com.br (M. L. Secundua), ajfazenda@yahoo.com.br (A. J. Fazenda) \\ ${ }^{*}$ Corresponding author
}

\section{To cite this article:}

Maria Lusinga Secundua, Augusto José Fazenda. Education for Health in Communities with Weak Basic Sanitation in Sumbe. Journal of Human Resource Management. Vol. 7, No. 1, 2018, pp. 11-17. doi: 10.11648/j.jhrm.20190701.12

Received: October 16, 2018; Accepted: December 22, 2018; Published: June 11, 2019

\begin{abstract}
The present study was conducted to diagnose the quality of the practice of the Nursing Technician in Health Education in communities with poor basic sanitation, in Sumbe, Kwanza Sul province, Angola. The sample consisted of the Nursing Technicians who work in the fishing communities of Karimba, Kikombo and Salinas de Ngunza, in Sumbe, and the managers of the health sector of the municipality and the province. The survey, interview and participant observation were used as methods and the main conclusion obtained was that there are weaknesses in the practice of health education, what hinders its promotion.
\end{abstract}

Keywords: Health, Nursing Technician, Health Education, Basic Sanitation, Quality of Life

\section{Introduction}

The health of people is deficient in most of the world due to the diseases caused by vectors and rodents that proliferate in communities with poor basic sanitation [1]. The main diseases which place humanity at risk are cholera, typhoid fever, hepatitis A, acute diarrhea, acute bacterial conjunctivitis, tuberculosis, malaria, schistosomiasis, intestinal helminthiasis (scabies, hookworm trichuriasis) Japanese encephalitis and yellow fever, all of them related to poor basic sanitation [2, 3]. The situation in this area is critical in Angola, due to the weaknesses of the system of orientation to the population to identify risk factors and assume healthy lifestyles.

To organize hygienic sanitary conditions to protect the life and well-being of the population, health education is necessary, individually and collectively, so that people understand their role and implement actions for healthpromotion with the aim of making it sustainable. This is understood as "development based on environmental management that meets the needs of the present generation without compromising the balance of the environment and the possibility that future generations could also meet their needs" [4].
Camacho and Ariosashow that "environmental management is a set of actions aimed at the administration, use and management of resources and the conservation, preservation, improvement and monitoring of the environment on the basis of coordinated information and citizen participation" [5]. With this objective in mind, the World Health Organization (WHO) guides states to work with educational institutions and the health sector in health education [6].

The training content of the Nursing Technician includes health education and it is developed as a transversal axis in the education and teaching process of children and young people in the schools of the world, nevertheless in most of the underdeveloped countries its implementation is deficient.

Researches in this area explain that in the Middle Age in Europe, there were no sanitation services and highlight that only the Roman cities and Roman villas had elements of sanitation systems. The water supply in the streets of cities and drains for the collection and disposal of wastewater from populated areas were rare and "unhealthy and overcrowded conditions were widespread throughout Europe and Asia at the time, what periodically led to catastrophic pandemics such as the plague of Justinian (541-542) and the Black Death (13471351), which killed tens of millions of people and radically altered society" [7]. 
Martinho and Gonçalvesreport that the municipal sanitation services, the collection of solid urban waste, the cleaning of the streets and the sewage system thatwere developed at the beginning of the 20th century in Western Europe contributed to many scientific discoveries in the area of public health what caused a pressure of public opinion and forced the governors to take measures of sanitation toimprove the collective well-being [8].

In African countries "the lack of financial resources and infrastructures result in the inefficient handling of municipal cleaning services. At the same time, the absence of actions and negligence on the part of local governments also contribute considerably to the aggravation of the situation" [9]. These are some of the weaknesses in Africa in general and Angola in particular; this countryshows a precarious situation in most of its territory.

The deficient basic sanitation that Angola has, most of all in rural and peri-urban communities contributes to the appearance of infectious and parasitic diseases that overburden the state in the planning of resources to minimize the mortality of children, young people and pregnant women [10].

The main antecedent of this work was the research published with the title Training in Environmental Education for Solid Waste Management of the General Hospital of Kwanza Sul whose aim was to unfold the risks that result from the inadequate management of the hospital solid waste in Sumbe; the appearance of pockets of mosquitoes that transmit malaria and flies that contribute to the transportation of bacteria associated with the emergence of acute diarrheal diseases. The results of this research lead to the training of Sumbe's general hospital work teams, from the cleaning assistant to the doctor, in environmental education aimed at the adequate management of solid waste.

The high amount of urban waste that results from the culture of innecesary consumption and other aspects related to the solidarity of the family and friends with the inmates in hospitals, what produces damages to the economy and consequently to the environment, as well as toxic and contaminated waste that damages health.

The present research shows the need to implement the practice and knowledge of the Nursing Technician in Health Education in communities with poor basic sanitation, in order to raise the awareness of the population to improve their living conditions through their participation in bettering up environmental and sanitary conditions. The study was conducted to diagnose the practice of Nursing Technicians in Health Education in communities with poor basic sanitation, in Sumbe, Kwanza Sul province, Angola. The sample consisted of the Nursing Technicians who work in the fishing communities of Karimba, Kikombo and Salinas de Ngunza, in Sumbe, and also the managers of the health sector of the municipality and the province.

The present research is based on the Puga researcher's definition, which states that "the nurse's training process should be centralized in a broad professional profile, which must perform its services taking into account the biopsychosocial unit of the human being from an integral point of view, considering educational, preventive, curative and rehabilitative elements and always acting within a framework of humanistic reference, with a solid scientific background" [11]. The nursing technician, in his way of acting, must contribute to health promotion that "consists in providing the people with the necessary means to improve their health and exercise greater control over it" [12].

In the world, research on health education is carried out in a systematic combination with the promotion of health in education systems. The training of health professionals, education for health promotion, educational, preventive and outreach strategies for the prevention of various diseases are common in many countries of the world, but in underdeveloped countries there are few studies about the occurrence of diseases and their relationship with health education in communities with poor basic sanitation.

Torres highlights that Health Education refers to "the possibilities of learning created consciously with a view to facilitating behavioral changes towards a predetermined goal" [13]. This author emphasizes that it is "an educational activity designed to expand the population's knowledge in relation to health and develop understanding and personal skills that promote health" he also explains that education for health is a pedagogical concept aimed at improving the quality of life of the people what is closely linked to the prevention of diseases, as a susceptible mean to modify the behaviors identified as a risk factor for certain diseases.

Torres and Fernández investigated the contextual situation of health and the need for training a higher level professional, as one of the health promotion strategies in Angola [14]. The experience in this subject is directed, fundamentally, to the development of studies on the characterization of the epidemiological picture of the country, but the curative and assistance strategies and actions for the professional improvement of the Technicians in Nursing in Health Education in communities with poor basic sanitation are not developed in the research.

The World Health Organization (WHO) explains that basic sanitation is the activity related to the supply of drinking water, management of rainwater, sewage collection and treatment, urban cleaning, solid waste management and control of pests and any type of pathogenic agent, with the aim of improving the health of the community. All these are fundamental factors in health promotion which are deficient in the peri-urban and rural communities of Angola, where the manifestation of parasitic and infectious diseases are very high.

Batista and Santana point out that "basic sanitation is the set of measures that aim to preserve or modify environmental conditions in order to prevent diseases and promote health and also improve the quality of life of the population and the productivity of persons what facilitates the economic activity" [15]. The aforementioned definition makes possible to understand the relationship of basic sanitation with the prevention of diseases and the improvement of the quality of life of the population, to which the practice of the Nursing 
Technician in Health Education in the communities will contribute.

At present it is considered important to act on the determinants of health, together with prevention and assistance actions. The WHO encourages the states to direct, from their policies, the health problems that affect the population and to develop strategies and initiatives to allow the improvement of people's quality of life through health education as the main element of the proposals for health promotion [16].

Angola implements a policy that meets the demands of international organizations to promote the improvement of people's quality of life, but it has so far failed to master basic sanitation in the communities [17]. After the national independence of Angola achieved on November 11, 1975, the Permanent Commission of the National Assembly, with the aim of promoting the health of the population, approved the Sanitary Regulation which is expressed in Law No. 5/87 of February 23, 1987, which changed the previous legislation called Portaría no 6392, of August 9, 1948, that deals with the General Regulations of Urban Health and the Sanitary and Mortuary Police of the Colonia de Angola, in the context of province of Portugal [18].

The aforementioned law constitutes an important framework for understanding Angola's efforts to protect the environment and promote the health of people. Among the objectives of the law in reference is the sanitation of the environment, in particular of human conglomerates, public enclosures and rooms; the application of measures aimed at improving protection and hygiene in work premises; the application of prophylactic measures and control of transmissible diseases, especially those of an epidemic nature, so as the hygiene of food and drinking water.

The long-term Development Strategy for Angola states that the development of multisectorial activities of the various institutions and organizations responsible for the creation of the necessary conditions for individual and collective well-being and the preparation of qualified personnel for the development of education for health is vital and urgent [19].

The Constitution of the Republic of Angola raises to the category of fundamental tasks of the state, the progressive creation of the necessary conditions to make effective the economic, social and cultural rights of citizens; promotion of well-being, social solidarity and the improvement of the quality of life of the angolan population so as the protection of the environment and establishes the right of people to basic sanitation through article 39 which expresses the "Right to the Environment" by declaring that "everyone has the right to live in a healthy and uncontaminated environment, as well as the duty to defend it and preserve it" [20].

In its article $219^{\circ}$, the Constitution of the Republic of Angola, attributes the responsibility of basic sanitation to the municipal administration, called local autarchy, which, as a whole, has little capacity to respond to the demands related to the supply of drinking water, collection and treatment of urban solid waste and the creation of sewage collection networks.

The strategic orientations of the National Health Development Plan (PNDS) in Angola, integrate "the mobilization of the population towards the health promotion of the communities with the aim of contributing to sustainable development, the struggle against poverty and the adoption, by the families, of lifestyles favorable to health, improvement of the environment the access to drinking water so as the training of families and communities " [21]. (Vol. 1, p. 34).

The PNDS presents an epidemiological picture of Angola is characterized by the prevalence of infectious and parasitic diseases that are more frequent in communities with poor basic sanitation, among which the transmissible diseases are close to $80 \%$ malaria, acute respiratory diseases and acute diarrhea account for more than $90 \%$ of the deaths in the country. Children under the age of 5 and pregnant women are the most vulnerable groups.

In health services, malaria accounts for about $35 \%$ of the demand for curative care, $20 \%$ of hospital admissions, $40 \%$ of the prenatal deaths and $25 \%$ of maternal mortality. The document states that tuberculosis is currently one of the most serious public health problems in Angola, as this disease assumes proportions of a genuine national disaster (Vol. 1, p. 23).

To solve these problems, the long-term Development Strategy for Angola proposes the implementation of vector control actions and prevention measures in the population, as well as information, education and community mobilization to improve knowledge, attitudes and practices, personal and collective, in the communities in regard to the transmission, prevention and curative measures, but in practice, the development of educational actions is insufficient.

The aforementioned strategy highlights the need to "improve basic sanitation through environmental health actions aimed at improving the situation of the peri-urban areas of large cities, such as the removal of garbage, sewage water conditioning and drinking water supply, to minimize the factors that facilitate the development of acute diarrheal diseases, acute respiratory infections and vectors of other transmissible diseases" [22].

Although efforts are being made in Angola to solve the health problems faced by the population in the province of Kwanza Sul, the Provincial Department of Public Health and Endemic Control in Sumbe reported that "close to 400 deaths are caused by malaria every year, 75 are caused by acute diarrheal diseases and 89 result from other diseases where the majority of victims are children under 5 years of age" [23]. Deaths caused by these diseases occur, above all, in poor communities with poor basic sanitation and weak preparation of people in health education.

In the province of Kwanza Sul, researchers Bapolo and Secundua investigated the need for the prevention of transmissible diseases such as malaria and tuberculosis and expressed the need of professional improvement of the nursing technician, but, so far no studies were found in Sumbe that relate health education in communities with poor 
basic sanitation $[24,25]$. In order to solve or minimize the public health problems that are related to poor basic sanitation it is necessary to consider the social responsibility of the Nursing Technicians who constitute a group with specific functions, within the health professionals, as they are trained to solve the main problems in the communities.

The Basic Law of Education and Teaching System (Law ${ }^{\circ}$ 17/16 of October 7, 2016), in Angola, states that "Education is a planned and systematized process of teaching and learning to fill the demands of individual and collective life" [26]. So the training of the Nursing Technician is based on the relationship of education with life and it is aimed at promoting health and achieving transformations in the lifestyles of the population.

In Angola, the Education and Teaching System faces the challenge of forming a competent Nursing Technician, who be committed to the citizenship, aspect that is declared in the Nursing Technician Training Plan [27]. The main practices proposed for these technicians are:

1. To characterize, in the community, the forms of water supply and destination of solid waste, associating them with the occurrence of diseases so as to indicate measures of protection and control of resources in the community.

2. To develop health education programs for groups, according to the needs identified, and the development of content and strategies of pertinent actions.

3. To characterize the ways of working and living of the community, with the identification of the components that damage their health and also to indicate the measures of protection and control.

4. To be able to know and intervene on the health problems and diseases with more prevalence in the national epidemiological profile, with emphasis on the region of action so as to identify the biopsychosocial dimensions of its determinants.

5. To train himself and act with sense of responsibility and commitment to the citizenship as a promoter of the integral health of the human being.

In this area, as a promoter of the integral health of the human being, the mode of action of the Nursing Technician, in Angola, requires him to develop health education with the view of promoting healthy lifestyles in the communities. Therefore, this research carried out in the communities, verified that the practice of the Nursing Technician in health education is weak.

\section{Method}

The survey, the interview and the participant observation were used as methods.

1. The Survey was addressed to 32 Nursing Technicians with the aim of obtaining data about their practice in health education, with the intention of measuring how they explain to the population the occurrence of diseases related to poor sanitation in the community. The survey was distributed at the health centers of the communities where the Nursing Technicians work and the key issue was to obtain information on their knowledge about the current situation of basic sanitation in the target communities in regard to the supply of drinking water, the treatment given to waste water, and the form of collection, treatment and final disposal of solid waste. The results of the survey revealed the relationship between the occurrence of diseases and the weaknesses of basic sanitation in the communities.

2. The interview made to the directors of the Provincial Health Department during the research was based on their knowledge about the contribution of nursing technicians to health education in communities with poor sanitation. To carry out the work were interviewed four heads of department, namely the Departments of Public Health, Inspection, Water and Sanitation and Hygiene and Epidemiology. The fundamental issues were the knowledge of the leaders about basic sanitation and its relationship with the occurrence of diseases and the practice of the Nursing Technician in Health Education in the communities. The results obtained are presented along with their discussion.

3. The authors of this research have been living in the communities under study and the observation guide was designed to deepen the knowledge about the existence of latrines and toilets, the way of collection, treatment, transportation and final disposal of solid wastes; sources and quality of drinking water in the communities so as to obtain data related to the knowledge that the population reveals about the occurrence of diseases that result from deficient basic sanitation. The field work favored the triangulation of the data obtained from the surveys and the interviews, what allowed to infer that there are weaknesses in the practice of the Nursing Technician in Health Education regarding the occurrence of diseases in communities with poor sanitation due to the lack of communication about the target issues.

\section{Results and Discussion}

Location of the communities under study

Sumbe is a municipality and a city in Angola, capital of the province of Kwanza Sul, made up by the headquarters communes (Sumbe), Gangula, Gungo and Kikombo. The municipality has about 290,295 inhabitants. In relation to weather, generally, its temperature, in Summer is $27^{\circ} \mathrm{C}$ and $22^{\circ} \mathrm{C}$ in Winter, the wind is $\mathrm{SW}$ at $11 \mathrm{Km} / \mathrm{h}$ and the humidity is $80 \%$. The community of Kikombo is located in the commune with the same name, Karimba is located in the commune of Gangula and Salinas de Ngunza is in the commune of Sumbe. Those communities are limited by the line of the Atlantic Ocean to the West.

Results of the survey to Nursing Technicians

The municipality of Sumbe controls 119 Nursing Technicians. The survey was applied to 32 of them, what 
makes up $27 \%$ of the total. The following answers were obtained from the surveys:

Regarding the deficient basic sanitation, 31 of the Nursing Technicians, that represent $96.8 \%$ of the participants, declared that they know the situation in the communities and 1 that represents $3.2 \%$ did not answer the question. In the opinion of the authors, although the technicians know the situation of poor basic sanitation in the communities, this knowledge is not used to encourage the change of behaviors for the prevention of diseases, since they only holder talks with the patients who seek the services of health and obtain medicines in the medical consultation. Health education must be developed in the community to promote healthy lifestyles and minimize health risks.

About water supply, 8 Technicians that represent $25 \%$ of the sample declared that they obtain drinking water from faucets, 19 that represent $59.4 \%$ expressed that they obtain it from tanker trucks, 1 which represents $3.1 \%$ answered that he takes it from the well, 1 which represents $3.1 \%$ declared that he takes it from the faucets and tankers and 3, which represent $9.4 \%$, obtain water for consumption from the river. The results revealed that Nursing Technicians, although they have the notion of health risk for the community when they consume untreated water, do not develop health education to contribute to the domiciliary treatment of drinking water.

In relation to the collection of solid waste, 11 Nursing Technicians that represent $34.4 \%$ explained that there is a solid waste collection service, 20 that represent $62.5 \%$ denied the existence of the service and 1 that represents $3.1 \%$ did not respond to that question. According to the data obtained, can be deduced that the Nursing Technicians assume that there are weaknesses in the communal services of solid waste collection and the participant observation made confirmed that these services do not exist in the communities under study.

29 Nursing Technicians which represent $90.6 \%$ stated that there is a relationship between Basic Sanitation and the diseases that occur in the community, 2 which represent $6.2 \%$ denied the existence of that facility and 1 which represents $3.1 \%$ did not answer the question. The authors consider that the responses of Nursing Technicians who assume that there is a relationship between basic sanitation and diseases are consistent with the profile of their training, an important aspect when demanding that health education be developed in the community.

The 3 Nursing Technicians who stated that there is no such relationship revealed weaknesses in the assimilation of the contents of Basic Sanitation during their training, what makes the practice of health education difficult. Those who deny the relationship between Basic Sanitation and diseases, although they represent a low percentage of the total of the group, are an important indicator and reveal the need for professional improvement.

Out of the total of 32 Nursing Technicians who participated in the survey, 30 that represent $93.8 \%$ develop health education, 1 which represents $3.1 \%$ denies the realization of that activity and 1 which represents $3.1 \%$ did not answer the question. The technicians who develop health education demonstrate the importance of raising awareness of the population in the prevention of diseases; however they do not systematize the contents and therefore produce insufficient positive effects to change the behavior of the population. Nursing Technicians who assume that they do not perform health education, have weaknesses related to their education and that is the reason why professional improvement to favor the sustainable development of the communities is proposed.

Results of the interviews with public health managers in the research: 4 heads of the Provincial Health Directorate were interviewed, including the Head of the Department of Public Health, the head of the Inspection Department, the head of the Section of Hygiene and Epidemiology and the Water and Sanitation Supervisor. The interview was based on one question dealing with their: knowledge of Basic Sanitation and its relation to diseases in the communities and another related to the practice of the Nursing Technician in Health Education in the communities

The leaders demonstrated that they have knowledge of basic sanitation; they considered that it is a set of measures for the control of all environmental factors that interfere in the health of the population. They reported that between 65 and $70 \%$ of the population has water of quality, due to the effort of the government that implemented the faucets in the communities and declared that the solid waste collection services exist only in the urban area, that is to say about $50 \%$, but in the peri-urban communities there is no regularity this service.

Regarding the relationship between basic sanitation and the diseases that occur in the communities, the heads of departments considered that the improvement of basic sanitation lowers the rate of diseases, and that is why it is considered pertinent to study the practice of Nursing Technicians in Education for health in communities with poor basic sanitation.

The authorities stated that the Nursing Technicians perform lectures in the health units about various topics, such as the signs and symptoms of malaria, the importance of vaccination and consultation of pregnant women, general hygiene, correct use of the mosquito net, use of latrines, prevention and treatment of acute diarrheal diseases, cholera, acute respiratory diseases, anemia, HIV \& AIDS, malnutrition, hypertension and diabetes mellitus, among other diseases. Although the leaders identified the topics that are developed in the medical centers, the participant observation made allowed to determine that there are weaknesses in the practice of health education, especially in the subject that deals with the relationship between basic sanitation and the diseases in the communities.

The leaders said that Nursing Technicians should develop education for health in the community and not only limit their work to educate the patients who appear in health units, what confirms the weakness that exists in that direction. So the interview with the authorities concluded that there are weaknesses in developing education for health in the 
communities.

The participant observation carried out in the communities with deficient basic sanitation allowed to determine that there are faucets of drinking water in the community of Salinas de Ngunza, but in that community there are no regular solid waste collection services. In the other communities under study, there are no potable water faucets or solid waste collection services and $60 \%$ of the population in communities with poor basic sanitation defecate in the open air. These results reveal the need of Health Education in the communities to raise awareness among the population in regard to disease prevention and health promotion.

\section{Conclusions}

Nursing Technicians who do not perform health education demonstrate weaknesses in their training and Nursing Technicians who practice health education do not systematize the contents of basic sanitation and its relationship with infectious and parasitic diseases, what proves that there are insufficient positive effects to change the behavior of the population in regard to health promotion. The authors arrived to the conclusion that there are weaknesses in the practice of Nursing Technitians in health education, what hinders the promotion of health in communities with poor basic sanitation.

The heads of the health sector of the municipality and province reaffirmed that there are weaknesses in the practice of Nursing Technicians in health education in communities with poor basic sanitation.

The participant observation that took place in the communities with poor basic sanitation found out that there are faucets of drinking water in the community of Salinas de Ngunza, but in that community there are no regular solid waste collection services. In the other communities under study, there are no potable water faucets or solid waste collection services and $60 \%$ of the population of communities with poor basic sanitation defecate in the open air. All these elements show the need of Education for Health in the communities, to make the population aware of the necessity of prevention of diseases and health promotion.

To prevent diseases in the communities with deficient basic sanitation by means of health education, is compulsory that the Health Technicians be prepared more rigorously and a systematic verification of their work be made.

\section{References}

[1] Jong-wook, L. Relación del agua, el saneamiento y la higiene con la salud. Organización Mundial de Salud. 2004. [CitedSeptember 14, 2018] Available at: http://www.who.int/water_sanitation_health/facts2004/es/http: //www.who.int/water_sanitation_health/WSHFactSpanish.pdf?ua $=1$.

[2] Batista, M. and Santana, A. (2012). Manual de SaneamentoBásico. 62p. [Internet][Cited September15, 2018] Available http://www.tratabrasil.org.br/datafiles/uploads/estudos/pesquis a16/manual-imprensa.pdf.

[3] Manual de Saneamento Básico. $3^{\mathrm{a}}$ ed.rev. Fundação Nacional de Saúde. Ministério da Saúde. 362 p. Brasil. 2006 [Cited September 15, 2018] Available at: http://www.bvsde.paho.org/bvsaia/p/fulltext/manual/manual.p df.

[4] Lei de Base do Ambiente. Angola. 1985.

[5] Camacho, A. and Ariosa, L. Diccionario de términos ambientales. Publicaciones Acuario. Centro Félix Varela. Habana. Cuba. 2000. ISBN: 959-7071-16-9.

[6] Carta de Otawa. Organización Mundial de Salud. [Internet] [citedSeptember17, 2018] Available at: http://www.fmed.uba.ar/depto/toxico1/carta.pdf.

[7] Cordero, M. Propuesta de intervención comunitaria encaminada a potenciar el saneamiento ambiental en las comunidades. Capítulo 1.4 Consideraciones teórico-históricas del saneamiento ambiental en las comunidades. [CitedSeptember 17, 2018] Available at: http://www.eumed.net/librosgratis/2012b/1203/consideraciones_teorico_historicas.html.

[8] Martinho, M. y Gonçalves, M. (2000). Gestão de Resíduos Sólidos. UniversidadeAberta. Portugal.

[9] Bernardo J. Uma Proposta Metodológica para a Gestão de Resíduos Sólidos na África. [Internet]. Recife; 2008. [CitedSeptember 11, 2018]. Available at: http://www.didinho.org/Arquivo/UMAPROPOSTAMETODO LOGICAPARAAGESTAODERESIDUOSSOLIDOSURBAN OSNAAFRICA.pdf.

[10] Estratégia de Desenvolvimento a longo Prazo para Angola. Vol. III. Ministério do Planeamento. República de Angola. 2004.

[11] Puga, A. (2007), Modelo para el desarrollo de la asistenciabilidad en el proceso de formación del profesional de enfermería. Tesis presentada en opción al grado científico de Doctor en Ciencias Pedagógicas. Centro de Estudios de Ciencias de la Educación "Enrique José Varona". Universidad de Camagüey. Habana.

[12] Declaración de Yakarta sobre la Promoción de la Salud en el Siglo XXI. Organización Mundial de Salud. Available at: http://www.mscbs.gob.es/profesionales/saludPublica/prevPro mocion/promocion/glosario/yakarta.htm.

[13] Torres, M. (2013) Promoción de la salud en sistemas educativos. Vol. 1. Instituto Pedagógico Latinoamericano y Caribeño, IPLAC. Universidad de Ciencias Pedagógicas Enrique José Varona (UCP EJV). Ministerio de Educación. Cuba.

[14] Torres, F. and Fernández, M. (2015). Proyecto cubano para formación de licenciados en enfermería, principales resultados. Cubango, Angola. [Cited February 16, 2018]. Available www.revinfcientifica.sld.cu/index.php/ric/article/view/182 7.

[15] Batista, M. and Santana, A. (2012). Manual de SaneamentoBásico. 62p. [Cited September 15, 2018]. Available at:

http:/www.tratabrasil.org.br/datafiles/uploads/estudos/pesquisa16 /manual-imprensa.pdf. 
[16] Declaración de Yakarta sobre la Promoción de la Salud en el Siglo XXI. Organización Mundial de Salud. Available at: http://www.mscbs.gob.es/profesionales/saludPublica/prevPro mocion/promocion/glosario/yakarta.htm

[17] Plano Nacional de Desenvolvimento Sanitário. Volume 2. Angola. 2012. [Cited September 21, 2018]. Available at: https://www.mindbank.info/item/3460.

[18] Regulamento Sanitário. República de Angola. 1985.

[19] Estratégia de Desenvolvimento a Longo Prazo para Angola. VolumeIII. Ministério do Planeamento. República de Angola. 2004.

[20] Constituição da República de Angola. 2010. [Cited July 15, 2018]. Available http://www.wipo.int/wipolex/en/text.jsp?file_id=409390.

[21] Plano Nacional de Desenvolvimento Sanitário. Volume 2. Angola. [Cited September 21, 2018]. Available at: https://www.mindbank.info/item/3460

[22] Estratégia de Desenvolvimento a Longo Prazo para Angola. VolumeIII. Ministério do Planeamento. República de Angola. 2004.
[23] Fazenda, A.; Manuel, A. and Aguilera, L. (2015). Capacitación en Educación Ambiental para la Gestión de Residuos Sólidos del Hospital General del Kuanza Sul. Centro de Desarrollo de las Ciencias Sociales y Humanidades en Salud. Camaguey. Cuba. In: Humanidades Médicas 2015; 15 (2): 241-261. Available at: http://www.humanidadesmedicas.sld.cu/index.php/hm/article/vie w/686/487http://scielo.sld.cu/pdf/hmc/v15n2/hmc03215.pdf.

[24] Bapolo, A. (2007). Assistência de Enfermagem aos Pacientes com Malária no Hospital Geral "17 de Setembro" no Sumbe, Kwanza Sul, Angola. Trabalho de fim de curso para obtenção do grau de Licenciatura em Ciências de Enfermagem. Universidade Agostinho Neto. Angola.

[25] Secundua, M. (2007). Assistência de Enfermagem aos Pacientes com Tuberculose Pulmonar no Hospital Geral "17 de Setembro" no Sumbe, Kwanza Sul, Angola. Trabalho de fim de curso para obtenção do grau de Licenciatura em Ciências de Enfermagem. Universidade Agostinho Neto. Angola.

[26] Lei de Base do Sistema de Educação e Ensino. República de Angola. 2016.

[27] Plano Curricular de Formação do Técnico Médio de Enfermagem. Instituto Técnicode Saúde do Kwanza Sul. Angola. 2010. 